\title{
LARGE SCALE INSTITUTIONAL CHANGES: LAND DEMARCATION WITHIN THE BRITISH EMPIRE
}

\author{
Gary D. Libecap \\ Dean Lueck \\ Trevor O'Grady \\ Working Paper 15820 \\ http://www.nber.org/papers/w15820
NATIONAL BUREAU OF ECONOMIC RESEARCH
1050 Massachusetts Avenue
Cambridge, MA 02138
March 2010

Research support was provided by the National Science Foundation through grants SES-0518572 and 0817249; and the Cardon Endowment for Agricultural and Resource Economics at the University of Arizona. An earlier version of this paper was presented at the Conference in Honor of Ronald Coase at the University of Chicago, December 4-5, 2010. The views expressed herein are those of the authors and do not necessarily reflect the views of the National Bureau of Economic Research.

NBER working papers are circulated for discussion and comment purposes. They have not been peerreviewed or been subject to the review by the NBER Board of Directors that accompanies official NBER publications.

(C) 2010 by Gary D. Libecap, Dean Lueck, and Trevor O'Grady. All rights reserved. Short sections of text, not to exceed two paragraphs, may be quoted without explicit permission provided that full credit, including $\odot$ notice, is given to the source. 
Large Scale Institutional Changes: Land Demarcation Within the British Empire

Gary D. Libecap, Dean Lueck, and Trevor O'Grady

NBER Working Paper No. 15820

March 2010

JEL No. D23,K11,N51,N53,Q15,Q24

\begin{abstract}
$\underline{\text { ABSTRACT }}$
This paper examines the economics of large scale institutional change by studying the adoption of the land demarcation practices within the British Empire during the 17th through 19th Centuries. The advantages of systematic, coordinated demarcation, such as with the rectangular survey, relative to individualized, haphazard demarcation, such as with metes and bounds, for reducing transaction costs were understood by this time and incorporated into British colonial policy. Still, there was considerable variation in the institutions adopted even though that the regions had similar legal structures and immigrant populations. We study the determinants of institutional change by developing an analytical framework, deriving testable implications, and then analyzing a data set that includes U.S., Canadian, Australian, and New Zealand temperate colonies using GIS data. We find that a simple framework that outlines the costs and benefits of implementing the demarcation systems can explain the different institutions that are observed. Once in place, these institutions persist, indicating a strong institutional path dependence that can influence transaction costs, the extent of land markets, and the nature of resource use. The agricultural land institutions that we examine remain in force today, in some cases over 300 years later. In this regard, institutions of land are durable, much as are other institutions, such as language and law.
\end{abstract}

Gary D. Libecap

Bren School of Environmental Science

and Management and Economics Department

University of California, Santa Barbara

Bren Hall 4412

Santa Barbara, CA 93106-5131

and ICER

and also NBER

glibecap@bren.ucsb.edu
Trevor O'Grady

Bren School of Environmental Science

and Management

University of California Santa Barbara

2400 Bren Hall

Santa Barbara, CA 93106

trevorogrady@gmail.com

Dean Lueck

Department of Agricultural and Resource Economics

Program on Economics, Law and the Environment

University of Arizona

Tucson, AZ 85721-0023

lueck@email.arizona.edu 
[I]n the absence of transaction costs, it does not matter what the law is, since people can always negotiate without cost to acquire, subdivide, and combine rights whenever this would increase the value of production. In such a world the institutions which make up the economic system have neither substance nor purpose.

$20^{\text {th }}$ Century British Economist Ronald Harry Coase ${ }^{1}$

I will only repeat the expression of my confident trust that you have sacrificed everything else to the one essential thing--the survey, the survey, the survey.

$19^{\text {th }}$ Century British Political Economist Edward Gibbons Wakefield ${ }^{2}$

\section{INTRODUCTION}

Institutions can change in dramatic fashion. For example, after conquest the victor can institute its language, law, currency, economic organizations, and form of government on the vanquished. In so doing it expands its institutional reach. ${ }^{3}$ Among these new institutions are those that govern land, perhaps the most fundamental of resources. A conquering regime can decide how property rights to land will be demarcated and assigned. Once implemented, absent another dramatic change, these institutions can persist.

In this paper, we examine the adoption of land demarcation systems within the British Empire in the $17^{\text {th }}$ through $19^{\text {th }}$ centuries. We focus on temperate colonies settled by British emigrants in North America, Australia, and New Zealand. ${ }^{4}$ The role of colonial emigration, as well as optimal land distribution and demarcation in the colonies were debated by leading political economists, including Adam Smith, Jeremy Bentham, John Stuart Mill, Thomas Malthus, David Ricardo, Edward Wakefield, and Robert Torrens (Winch 1965). The British Colonial Office (Labaree 1967, Vol. 2) and especially

\footnotetext{
${ }^{1}$ Coase (1989, p.14).

${ }^{2}$ See Wakefield, et al, (1868, p. 290)

${ }^{3}$ History is replete with such conquests and expansions - from Ancient Rome two millennia ago, to the British Empire between the $17^{\text {th }}$ and $20^{\text {th }}$ centuries, to the Soviet regime of the $20^{\text {th }}$ century.

${ }^{4}$ In this regard, we follow Acemoglu, Johnson, and Robinson (2001) and Crosby (1986) who also focus on the "Neo-Europes" where settlers tried to replicate European institutions. Primary examples of this include Australia, New Zealand, Canada, and the United States.
} 
Wakefield (1834) called for synchronized, planned settlement and land demarcation. As we show, however, there was considerable variation in the institutions actually adopted and we analyze the causes of that variation.

In his pioneering work Coase $(1937,1960,1989)$ was first to develop (or imply) a theory of institutional choice when posting that judges choose the most efficient legal regimes. This work led to discussions of the evolution of legal rules and indeed to the law and economics movement, and later to work on institutions by North (1990), North, Wallis, and Weingast (2009), Acemoglu, Simon, and Robinson (2001, 2002, 2005), and others. Moreover, as the quoted remark above notes Coase (1989) clearly understood that markets themselves are institutions that facilitate trade and indeed "require the establishment of legal rules" for them to function. ${ }^{5}$

Ironically, many of Coase's most famous examples have to do with land. In "The Problem of Social Cost" Coase used the example of land use conflicts between wheat farmers and cattle ranchers and his examination of English law focused on nuisance (i.e., land use) disputes. In his theory he discussed the importance of the "delimitation of rights" to land $(1960,8)$. Yet, Coase does not examine in detail how rights to land are actually demarcated, nor does Coase acknowledge that the demarcation of land in his native England is so different from his adopted home in Chicago. But, as Coase would certainly acknowledge, the practicalities of land demarcation are fundamental because they mold land markets and shape land use. Coase, of course, was not alone in overlooking land demarcation. There is little legal or economic scholarship on the factors influencing

\footnotetext{
${ }^{5}$ See Coase $(1989,10-14)$ and Scott $(1998,256,351)$ on the role of underlying institutions for markets.
} 
demarcation, and even major property law treatises (e.g., Dukeminier and Krier 2002, Merrill and Smith 2007) merely describe the dominant American system. ${ }^{6}$

We begin by briefly summarizing land demarcation in the British Empire. In section III we develop a framework for examining the decision to adopt particular demarcation systems. In section IV we examine the implications of our framework by examining the detailed history of land demarcation in the British colonies and by econometrically examining the determinants of those institutional choices. We summarize our study in section V.

\section{LAND DEMARCATION IN THE BRITISH EMPIRE.}

The British Isles comprise 121,673 square miles. At its peak, the British Empire covered 14,200,000 square miles, nearly 25 percent of the world's land area, and the

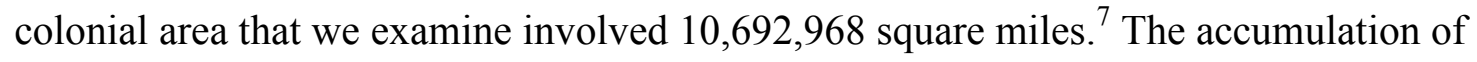
these vast expanses of land beyond the home islands generated the practical problems of how to allocate this land and how it should be demarcated. These decisions were influenced by the institutions that were developing within Britain at the time of expansion and the political economy debates that emerged around colonial policies.

\section{A. The British Isles.}

By the mid $17^{\text {th }}$ century, land in Britain was becoming more valuable and this led to changes in land institutions from traditional practices that subsequently influenced British colonial policy. For example, the enclosures of scattered and common lands helped to

\footnotetext{
${ }^{6}$ Neither of the comprehensive treatises on law and economics by Posner (2002) and Shavell (2007) mentions land demarcation. Demarcation, on the other hand, is examined by economic geographers in describing the use of mapping and cadaster systems. For example, see Scott (1998) and Kain and Baigent (1992). Libecap and Lueck (2009) and Libecap, Lueck and Lopes (2010) find that there are economically and statistically significant gains in land values from enactment of a systematic, rectangular survey in the United States.

${ }^{7}$ By comparison Africa comprises just 20 percent of the earth and Russia, the largest country is about 11 percent of the Earth. The total land area of the Earth is 57,308,738 square miles http://www.enchantedlearning.com/geography/continents/Land.shtml. See also Ferguson $(2004,15)$.
} 
restructure, reshape, and consolidate plots into more useful forms for sheep raising and larger-scale food production. Land that previously had been held and worked in common or in strips was reorganized into plots owned in severalty and in some cases merged into rectangular forms that were recognized as beneficial for production and trading. ${ }^{8}$ Land markets, which historically had been local and limited, became more active and broadly based (Darby, 1973, 302-53). To promote trades, Parliament intervened between 1660 and 1830 with roughly 3,500 Estate Acts to free property rights from traditional constraints of inheritance and other communal requirements (Bogart and Richardson 2009, 3; Richardson and Bogart 2008, 7-18).

These changes in land institutions required more accurate measurement and boundary definition and standardization of processes. More precise survey was made possible with new procedures and equipment, particularly the introduction of Gunter's chain in 1620, which spread throughout England and subsequently, to the English colonies. Gunter's chain helped to generalize use of a standard statute rod of $16 \frac{1 / 2}{2}$ feet for land measurement by surveyors. Other new equipment and practices included the Theodolite survey, use of telescopes, the solar compass, and triangulation survey emerged over time and influenced the costs and benefits of various demarcation systems. ${ }^{9}$

\section{B. The Temperate British Colonies.}

Figure 1 shows the British Empire colonies in North America, Australia, and New Zealand. The addition of these colonies opened vast amounts of new temperate land for

\footnotetext{
${ }^{8}$ Turner (1980), Young (1808) on enclosures in a very large literature. The emergence of rectangular fields as a result of some enclosures is noted by Yelling $(1977,120,123,131,138)$. For additional discussion of the geography of enclosure, see Kain, Chapman, and Oliver (2004). Scott (1998) 24-49 discusses the expansion of survey and drafting of cadastral maps in the $17^{\text {th }}-19^{\text {th }}$ centuries.

${ }^{9}$ Richeson $(1996,140-75)$ discusses the introduction and spread of Gunter's chain as well as other survey innovations. Linklater (2002, 13-20) describes the impact of Gunter's chain on measurement and the opportunity to firm private property rights to land.
} 
British immigrants. Abundant land in these regions offered the possibility of transplanting British farms, agricultural practices, crops, and land institutions. The question of how to design and manage colonization became part of British political economy debates in the $18^{\text {th }}$ and 19th centuries.

\section{[Figure 1 here]}

One issue was whether land should be allocated in a decentralized, unsystematic manner, with individual land claims and demarcation through traditional English metes and bounds. "Metes" refers to property boundaries defined by the measurement of distances between terminal points, and "bounds" refers to boundary descriptions based on topography. Under metes and bounds demarcation, parcels were surveyed independently after settlement and generally resulted in non-uniform, uncoordinated shapes, sizes, and alignment. $^{10}$

An alternative was to allocate and demarcate land in a more organized, systematic manner, with the survey of land parcels prior to distribution. Coordinated demarcation could be within a local area, organized by a particular colonial group or large land owner, or it might be broader, covering a larger jurisdiction, organized by a government. The rectangular grid was favored. ${ }^{11}$ Colonial towns often were laid out with square blocks (Thrower, 1966, 9), and Robert Torrens and Edward Gibbon Wakefield, two important $19^{\text {th }}$ century political economists and politicians, called for the strictly planned distribution of all

\footnotetext{
${ }^{10}$ See Libecap and Lueck (2009) for a discussion; also see http://en.wikipedia.org/wiki/Metes_and_bounds .

${ }^{11}$ The rectangular grid or rectangular survey (RS) is system of rectangles established to locate and specify boundaries for land parcels. In the U.S. Public Lands System Survey, the RS divides land into townships of 6 miles square, bounded by base lines running east and west, and meridians running north and south. Townships are further divided into 36 sections, each one mile square. Sections can be subdivided into quarter sections, quarter-quarter sections, and so on: http://www.nationalatlas.gov/articles/boundaries/a plss.html. A survey technique that used in the $19^{\text {th }}$ century was triangulation http://en.wikipedia.org/wiki/Triangulation. Triangulation involves measurement of the angles of a series of triangles to fix property location and boundaries. If done in an organized manner, parcels could be demarcated with respect to one another.
} 
colonial agricultural land and controlled settlement to create productive colonies (Winch 1965, 56-93). ${ }^{12}$ One element of Wakefield's Colonial Reform Movement was the survey of land into squares prior to sale an occupation (Winch, 1965, 113-45; Oldham, 1917, 4, 16, 74; Burroughs, 1967, 12-3). Squares offered potential productivity gains as well as clear boundaries and uniform parcels for exchange in land markets. ${ }^{13}$ Wakefield argued that allowing individualized claiming and demarcation with uncoordinated metes and bounds would lead to confusion, a lack of organization, and failure. The interests of individuals to independently claim land would diverge from the broader interests of colonial society, which would be molded by the way in which land was demarcated (Winch 1965, 137). The potential benefits of more centrally-controlled, planned demarcation were incorporated into circulars issued by the British Colonial Office in the late $17^{\text {th }}$ and $18^{\text {th }}$ centuries:

First, that you, our said governor....of our lands for the [northern, southern] district of North America....taking care that such districts so to be surveyed and laid out as aforesaid be divided into such a number of lots (each lot to contain not less than one hundred nor more than one thousand acres) as our survey general shall judge best adapted to the nature and situation of the districts so to be surveyed....That so soon as the said survey shall have been made and returned as aforesaid, you, our said governor or commander in chief of our said province.....appoint such time and place for the sale and disposal of the lands contained within the said survey to the best bidder ...". ${ }^{14}$

\footnotetext{
${ }^{12}$ Torrens, originally from Ireland, became Premier of South Australia and later a member of the British Parliament. He is widely known for creating the system of land registrations that goes by his name. Wakefield was a leading colonial policy theorist especially for the centralized demarcation of lands in South Australia, New Zealand, and later Canada. He was a Director of the New Zealand Company, co founder of the Colonial Reform Movement, and a member of the New Zealand Parliament.

${ }^{13}$ Other aspects of the Colonial Reform Movement included constraints on the supply of new lands made available at any point in time and high fixed prices. Studies by Barnes (1935) and Lee and Sallee (1974) show production advantages in rectangular fields where the farmer works parallel to the longest sides of the field. ${ }^{14}$ Labaree (1967, vol 2, 536). For similar instructions for various other colonies see Labaree (1967, vol 2 , $537,540,541,586-87)$.
} 
The potential advantages of the broad, uniform rectilinear demarcation of land also were recognized in the U.S. at the end of the colonial period during Congressional debates over the Land Ordinance of May 20, 1785 that ultimately resulted in the Public Lands Survey System. ${ }^{15}$ Congress rejected metes and bounds and instead called for survey before occupation with properties to be marked in squares, aligned with each other, "so that no land would be left vacant," to prevent overlapping claims, and to simplify registering deeds (Linklater, 2002, 68-70; White, 1983, 9).

\section{A Framework fOR EXAMining InSTITUTIONAL CHOICE}

In this section we examine the decision to adopt a particular land demarcation system. We first examine the simple stylized choice between a rectangular system (RS) and metes and bounds (MB). This analysis allows general predictions about the choice between these two dominant demarcation institutions. We then extend our model to consider the choice among these two regimes and a third intermediate regime also used in the British Empire. ${ }^{16}$

To begin, it is apparent that there are potential gains from centralized demarcation (Libecap and Lueck 2009). First, there can be enforcement cost savings from coordinating common borders, eliminating gaps of unclaimed land, and clarifying boundaries. Second, similarly aligned properties will eliminate oddly-shaped, unproductive parcels that arise with unsynchronized demarcation of large areas. Third, a common demarcation pattern provides information about the position of individual parcels. This information reduces potential for overlapping and conflicting claims; allows for a common address system; and importantly, lowers transaction costs, promoting land markets. Fourth, coordinated

\footnotetext{
${ }^{15}$ Ford (1910, reprinted 1976, 27, 55), Linklater (2002, 116, 117), Pattison (1957, 87).

${ }^{16}$ Our model follows Libecap and Lueck (2009).
} 
demarcation is a public good network that will have greater value as it is spread over a larger region.

An organized system with uniform parcels, such as the rectangular grid, provides the largest benefits with similarly shaped, sized, and aligned parcels, but it potentially entails higher costs than does an organized/non uniform system that has fewer constraints on parcel size and shape. An organized/non uniform system, however, provides fewer coordination benefits because parcels are no longer necessarily similar in shape and size. The third option, an unorganized metes and bounds demarcation system does not provide any of the benefits of organized demarcation, but it avoids the costs of controlled entry and delayed settlement and production until survey.

The economic decision to adopt a coordinated rectangular demarcation system relative to metes and bounds can be examined by comparing the total value of land under both arrangements. This expression is the sum of parcel values, less the costs of the systems themselves. Assume the Empire is considering land demarcation for a region (e.g., a colony) that is $A$ acres in size. We incorporate a temporal dimension to account for difference in system setup and continuation costs.

Under metes and bounds (MB) the net value of the land is the sum of individual values and costs, less the continuing costs associated with adjustments resulting from the lack of coordination, so that the total present value of the land in the region is

$$
V^{M B}=\int_{0}^{T}\left(V_{\tau}^{*}(A, t)-c_{0}(A, t)-C_{\tau}^{M B}(A, t)\right) e^{-r \tau} d \tau,
$$

where $V_{\tau}^{*}(A, t)$ is the optimal parcel value under MB at time $\tau, T$ is the time horizon, $\mathrm{t}$ is a parameter measuring topography which varies along the interval $(0,1)$ where 0 is flat and 
most valuable and 1 is vertical and least valuable, $r$ is a discount rate, $\mathrm{c}_{0}(A, t)$ is the onetime demarcation cost function, and $C_{\tau}^{M B}(A, t) \geq 0$ are the continuing costs of MB, including individual enforcement, border disputes, and misaligned parcels. Under MB land demarcation and output begin immediately at time $\tau=0$ and the continuing costs associated with MB are assumed to be increasing in the size of the region $(A)$ and rising over time $(\tau)$ as these problems accumulate.

Under a rectangular system (RS) the net value of land reflects the value of the network benefits of the system, such as the public goods of common addresses, survey coordination, as well as standardized, aligned, and fixed parcel boundaries. These network and coordination benefits come, however, at the cost of a necessarily extensive system, in which there are upfront costs of design, survey, and controlling access until demarcation is completed. $^{17}$

Individual land claimants under RS do not face demarcation costs as with $\mathrm{MB}$, so the total present value of the land in the region governed by RS is

$$
V^{R S}=\int_{0}^{T}\left(\bar{V}_{\tau}(A, t)\right) e^{-r \tau} d \tau-\int_{0}^{\tau^{\prime}}\left(C_{\tau}^{R S}(A, t)\right) e^{-r \tau} d \tau,
$$

where $\bar{V}_{\tau}(A, t)$ is the optimal value for the region at time $\tau$; and $C_{\tau}^{R S}(A, t) \geq 0$ is the cost of the system that occurs prior to claiming and use during the period from $\tau=0$ to $\tau=\tau$ '. Network effects are incorporated into the land value function, which is increasing in the area governed by the regime $A$ and because $\bar{V}_{\tau}(A, t)>V_{\tau}^{*}(A, t)$. The RS system costs are increasing in $A$, but at a decreasing rate, revealing network economies. These costs are also

\footnotetext{
${ }^{17}$ Our MB - RS cost distinction is similar to Dixit's (2003) distinction between local (informal) and large (formal-legal) trading systems, where the latter have greater setup costs like RS.
} 
increasing in topography. ${ }^{18}$ Because RS requires surveying before parcel selection, the time horizon for generating value from the land begins at $\tau^{\prime}>0$. It is efficient to implement RS when $V^{R S}-V^{M B}>0$ or when

$$
V^{R S}-V^{M B}=\int_{\tau^{\prime}}^{T}\left(\bar{V}_{\tau}-V_{\tau}^{*}\right) e^{-r \tau} d \tau-\int_{0}^{\tau^{\prime}}\left(V_{\tau}^{*}+C_{\tau}^{R S}\right) e^{-r \tau} d \tau+c_{0}+\int_{0}^{T} C^{M B} e^{-r \tau} d \tau>0
$$

This difference has four terms that illustrate the tradeoffs between a rectangular system and metes and bounds. The first term comprises the network gains from RS over MB. The second term is the gains from MB that would be sacrificed during the period the RS is being implemented, in terms of output under metes and bounds and rectangular system setup costs. The third term is the foregone individual demarcation costs under $\mathrm{MB}$ not required under RS, and the fourth term is the avoided continued costs of MB over the time horizon. From (3) comparatives statics emerge: the net value of RS will increase in the size of the governed land area $(A)$, increase in the expected time horizon $(T)$, and decrease in the time of RS implementation $(\tau)$. We thus expect the Empire is more likely to choose a rectangular land demarcation system when: a) the larger are the tracts of land under its control; b) the longer is the expected time horizon of its control; c) the more quickly the system can be implemented; and d) the greater the network benefits among the parties.

Considering forces likely to change the model parameters can illuminate these predictions. For instance, more rugged topography would reduce net gains from a rectangular system by increasing the costs and time of implementation and perhaps even by reducing the losses of sub-optimal parcel shape. Similarly a region with no recognized

\footnotetext{
${ }^{18}$ These effects are greater than with MB because more rigid squares are required, relative to flexible parcel shapes under MB.
} 
incumbent demarcation system existed will have lower rectangular system implementation costs. Third, greater political authority by the Empire and cohesion among the population will increase the expected time horizon of control, lower implementation times, and hence, make the adoption of a rectangular system more likely.

We now modify this framework to more closely link it to land demarcation regimes used within the temperate regions of the British Empire. As we discuss in detail in the next section, not only were RS and MB chosen but a third hybrid regime was also implemented as implied above. Table 1 summarizes these three demarcation regimes: the rectangular systems (RS), a hybrid or mixed system (MX), and metes and bounds (MB). The second regime can be generally characterized as providing some network benefits through planned demarcation and prior survey that are lower than RS because of the lack of parcel uniformity, but in certain environments had lower upfront survey costs due to less rigidity in parcel size, shape and arrangement.

\section{[Table 1 here]}

The value generated by the third hybrid regime (MX) can be seen as a modification of (3). Relative to MB, the hybrid has higher network gains as indicated in the first term because it is planned and coordinated, but fewer than those offered by RS because of varying plot sizes and shapes. The gains from $\mathrm{MB}$, as indicated in the second term are lower relative to MX as compared to RS, because the former has more flexible shapes and hence possibly lower set up times. The third and fourth terms, foregone individual demarcation costs, and avoided continued costs under MB are generally the same as with RS. The major difference then between RS and MX is that the former standardizes 
information through parcel uniformity, at the expense of a more rigid structure of its upfront costs.

Several predictions follow and are merely extensions of those derived above and are expected to be tightly connected to heterogeneity in the land and potential inhabitants. The Empire is more likely to choose the hybrid demarcation system a) the smaller and more variable in quality and topography are the tracts of land under its control; b) the shorter is the expected time horizon of its control; and c) the longer it takes for the colony-wide system can be implemented.

\section{EMPIRICAL ANALYSIS.}

To test these predictions about the choice in land demarcation institutions in the British Empire we employ two methods. First, we examine the history of colonial land demarcation by examining the literature and the contemporary political debates. Second, we assemble a data base at the colonial level which includes information on demarcation institutions and on exogenous land characteristics.

\section{A. Framework Predictions and Demarcation across the Temperate Colonies.}

The framework predicts that time of ownership or control by the Empire and the lack of incumbent demarcation practices should raise the likelihood of observing systematic demarcation, such as the rectangular survey. These two factors did not vary across the temperate colonies. By the time Britain was establishing its North American, Australian, and New Zealand colonies in the $17^{\text {th }}-19^{\text {th }}$ centuries, it was the premier world power, and this did not change significantly until WWI. Britain was the home of the industrial revolution beginning in the $18^{\text {th }}$ century; it defeated the Dutch and France in North America between 1664 and 1763; and faced no serious competition in Australia or New Zealand. 
Spain, another potential competitor, was driven from most of its western hemisphere colonies between 1810 and 1825 . Accordingly, Britain had secure control over its colonial territories, increasing the expected time path of returns of implementing new institutional forms.

In terms of local demarcation practices, indigenous peoples tended to be sparsely populated without formal demarcation of the land at least that was generally adhered to by Britain. The groups were militarily defeated, allowing the Britain to implement British land demarcation institutions across its temperate colonies (Linklater 2002, 24-40). ${ }^{19}$

The other factors described in the framework, however, do vary across the colonies, and we use this information to explain differences in observed land institutions. Although colonial towns often were laid out with lots following a rectangular grid, the demarcation of agricultural lands did not have such uniformity. Table 2 describes the different institutions found in the temperate colonies, following the classifications described above and organized by system.

\section{[Table 2 here]}

Figures 2 and 3 show examples of varying demarcation across the Empire. The discussion of practices across the colonies is ordered according to the type of regime that prevailed in each. Among the variables identified in the framework developed above, historical narratives provide information on the roles of a). Control over land and the population so that survey could precede settlement; $b$ ). Time of settlement that indicates access to newer more accurate survey techniques and equipment that lower the costs of RS;

\footnotetext{
${ }^{19}$ In the colonial period, only in New Zealand in the North Island were population numbers sufficiently large that natives had more political and military power requiring accommodation. See Hailey $(1938,713)$. Population estimates for the temperate colonies at the time of settlement are limited. Some sources include Borah (1976, 13-34), Pool (1977), Vamplew (1987).
} 
c). Terrain that influences both the costs of survey and monitoring control over settlement, as well as the returns to systematic demarcation if rough terrain reduces potential agricultural land value; and d). Soil quality that influences agricultural land values, farm size, and population densities. The network gains provided by RS increase in the number of parcels and farms and decline with lower intrinsic land value due to soil quality.

[Figures 2and 3 here]

\section{MB: The Southern American Colonies, the Middle Atlantic Colonies, New South Wales, Tasmania, Queensland, and Western Australia.}

These were all relatively early colonies, most established in the $17^{\text {th }}$ and early $18^{\text {th }}$ centuries so that settlement and demarcation took place with more primitive, costly survey instruments, making RS more difficult. Although there were early plans for more orderly, coordinated settlement and land demarcation through RS in the Georgia and South Carolina, these failed. ${ }^{20}$ There was little control over claimants in the southern American colonies. As colonial immigrants moved into the interior, land areas were indiscriminately selected, settled, and then surveyed in a haphazard manner using metes and bounds. As a result there was little consistency in parcel shapes, sizes, or alignment, and boundaries were vague. Swamps and irregular terrain also made more systematic survey difficult (Linklater $2002,32-40)$.

In the Middle Atlantic colonies, William Penn, who was granted the territory of Pennsylvania in 1681, also had envisioned an orderly land distribution with contiguous tiers of townships of 5,000 acres square, surveyed prior to settlement, moving west from the Delaware River as RS. But this generally did not occur in Pennsylvania or elsewhere in

\footnotetext{
${ }^{20}$ Marschner (1960, 22-24, 33-36), Kain and Baigent (1992, 269-76), Price (1995, 97 on free choice; see also 7, 15-18, 87-205 for discussion of the southern colonies), Thrower (1966, 10), Johnson (1957, 22), Kinda (2001, 143), Mitchell (1983).
} 
New Jersey, New York, and Delaware where there was only loose central control over the distribution of land, and parcels were haphazardly defined prior to survey as MB (Marschner 1960, 2734, 35; Price 1995, 212). The challenges of rough terrain and variable land quality for systematic demarcation in RS were noted by a surveyor in Lancaster County, Pennsylvania: "the habitable land lyes so in patches among the mountains and barrens that one tract canot always (nor often) lye contiguous with another, for that reason alone it will be very much to your loss if every man be allowed to take what quantity he things fit...And this I fear will often be the case if the warrants are issued before the tracts are survey'd."${ }^{21}$

Limited control, rough terrain and variable soil quality also led to MB in the early Australia colonies of New South Wales (1770), Tasmania (1803), Queensland (a part of New South Wales until 1859), and Western Australia (1826). New South Wales and Tasmania began as penal colonies for Britain and not initially as locations for emigration to new land. As a result, there was little constraint on internal migration and land claims. Although instructions to colonial governors called for British institutions to be implemented for planned centralized allocation and survey of land into small farms under RS, claiming and demarcation instead was much more ad hoc under metes and bounds.

In the interior, terrain was rough and in New South Wales, semi aridity resulted in large parcels being claimed and a dispersed population, reducing potential network gains from RS (Jeans 1966, 125-7; Jeans 1967, 243-54; Kain and Baigent 1992, 307-10). Efforts to implement Wakefield's plans for systematic survey and distribution via RS in 1821, failed. ${ }^{22}$ Tasmania, or Van Diemen's Land, was administered as part of New South Wales

\footnotetext{
${ }^{21}$ Quoted in Kain and Baigent (1992, 287-88), Price (1995, 207- 283).

${ }^{22}$ Winch $(1965,94-108)$, Jeans $(1966,119-23)$. Similar arguments are found in Jeans (1975).
} 
until 1824 with little planning or control over settlement or coordinated demarcation (Kain and Baigent 1992, 307; Jones 1989, 41). As predicted, rugged terrain raised the costs of developing townships with systematic rectangular survey. ${ }^{23}$ Most arable land was occupied by individuals and then surveyed under MB. The same terrain problems and lack of control over land claiming in Queensland led to the dominance of MB in that colony (Jeans,1966,122-23; Kain and Baigent,1992, 307). Although not adjacent to New South Wales, Western Australia faced similar problems of settlement prior to survey, coupled with very dry terrain and mixed soil quality that did not blend with a small, uniform land distribution policy. ${ }^{24}$

\section{Mixed: New England, Nova Scotia, Quebec, and New Zealand.}

In terms of timing all, but New Zealand (largely settled in the $19^{\text {th }}$ century), were very early colonies dating from the $17^{\text {th }}$ century. ${ }^{25}$ Quebec was colonized beginning in 1608 by France and French land demarcation was incorporated by the British. This timing suggests more primitive survey practices, which all things equal, would reduce the use of RS. These colonies also generally had rough terrain that raised survey costs. What distinguishes them from the previous group was greater control over land settlement and demarcation. In these colonies, survey occurred first before occupation, but terrain appears to have limited the use of RS. The result was a mixed demarcation system that varied across the colonies.

\footnotetext{
${ }^{23}$ Jones $(1989,75)$. Personal communication with Brownwyn Meikle, a post graduate student at the University of Tasmania who is studying early land policies, January 2010. See also McKay (1962) for discussion of Tasmanian survey and land demarcation. .

${ }^{24}$ Jeans $(1975,3-5)$ discusses the general problem in Australia of limited good farm land and dry conditions that favored pastoral pursuits, rather than farming. For problems in Queensland and Western Australia with squatting and "free homesteading, see Williams $(1975,94)$. See Kain and Baigent $(1992,307,309)$ for reference to unregulated distribution of land in huge parcels in West Australia (Swan River colony).

${ }^{25}$ New England included Massachusetts (1620, Plymouth, 1628, Massachusetts Bay Colony), Maine (1622), New Hampshire (1623), Rhode Island (1636), and Connecticut (1633). Nova Scotia was (1621), while New Zealand settlement largely occurred in the $19^{\text {th }}$ century after 1838 .
} 
In New England land was demarcated into (generally) square townships of 6 to 10 miles and internally divided into town lots and agricultural plots, including common fields. Proprietors distributed land to the township inhabitants. Within the township, properties were not of equal size or uniform shape, but based on social standing, wealth, and family size. Settlement was communal, often organized around religious groups from an existing community in England (Marschner 1960, 24, 25; Egleston 1886, 21-22, 41-45; Price 1995, 13-14, 28-29; Kinda 2001, 142). As settlers moved into the interior, they petitioned colonial governments for land grants that were distributed as new "towns" or townships (Kain and Baigent 1992, 285-86; Egleston 1886, 15). Lands were to be collectively to build a "compact state of freeholders" and were to be surveyed and marked within 12 months of the township grant. There was limited independent squatting on land (Egleston 1886, 15-18; Price 1995, 28-35.) Township locations were not coordinated and could be scattered. This organized pattern of survey and demarcation tended to weaken as migration moved further into the more rugged New England interior (Price 1995, 34-35).

Nova Scotia (1621) land demarcation patterns were similar to those in New England with local townships. In some cases townships were large, of 100,000 acres given to a collective group. Individual shares within the township could be up to 500 acres. The external township lines were surveyed prior to the grant and the township community was responsible for subdivision (Kinda $(2001,142)$, Thomson (1966, 118-120).

Quebec was made part of the British Empire in 1763 after the treaty of Paris. The French crown granted land to seigneurs who subdivided their grants into individual plots of 60-100 acres in long narrow lots that fronted the St. Lawrence River. The seigneurs then recruited colonists to occupy and rent their lands. In this way, the land was surveyed and 
demarcated prior to settlement in a manner similar to townships in New England (Harris and Guelke 1977, 135-53; Kain and Baigent1992, 276-98, 303; Thomson 1966, 38, 76-77).

Demarcation in New Zealand was affected by the control over settlement provided both by Wakefield's philosophies implemented by the New Zealand Land Company organized in 1838 (Winch 1965, 111-13) and improvements in surveying with triangulation that appeared by the $19^{\text {th }}$ century. Indeed, RS was the initial plan. Six (and later 10) provinces were established in New Zealand and each adopted a separate, but similar land demarcation system: Wellington, Nelson, Taranaki, Otago, Canterbury, and Hawke's Bay (Scott 1998, 51; Kain and Baigent 1992, 318, 319). ${ }^{26}$ The New Zealand Company's initial RS system worked to some degree in Canterbury, which was relatively flat, but ran afoul of rough terrain and other natural features that raised the costs of demarcating into square sections elsewhere. An alternative standardized survey system with variable parcel sizes, shapes, and alignment was adopted using triangulation. Triangulation provided systematic location, addresses, and well defined boundaries. It was first used in Otago and spread throughout all of New Zealand by 1876 (Kain and Baigent 1992, 320-24).

\section{RS: Federal Public Lands, Canadian Dominion Lands, Ontario, New Brunswick, South Australia, Victoria.}

These regions were settled relatively later, generally in the late $18^{\text {th }}$ and early to mid $19^{\text {th }}$ centuries; are characterized by flat terrain and fertile soil; and by effective land control. These factors appear to have encouraged survey prior to settlement into RS. There was clear government authority in the U.S. under the Federal Land Ordinance of 1785 (Public Lands System Survey, PLSS), where land was surveyed into 6 by 6 mile townships (480 chains per side) and subdivided into 36 sections of one square mile each before to sale

\footnotetext{
${ }^{26}$ They were combined into a single colony in 1876 . Through 1870 most agricultural settlement took place on the South Island (Greasley and Oxley 2009, 326).
} 
and settlement. ${ }^{27}$ The PLSS was inaugurated for the comparatively flat and rich soils of the Midwest and gradually extended across the Great Plains. The rectangular survey was adopted because of its ability to promote “...an orderly settlement of new lands," prevent the scattered and uneven claiming of only the best lands "...leaving vacant and uncultivated, in such irregularity, small and incommodious parcells that it is thought scarcely worth any one's While....," reduce land boundary conflicts and "prevent innumerable frauds and enable us to save millions", and importantly raise land values and revenue "...these Lands will provide a considerable resource for sinking the national debt, and, if rightly conducted, liten the burthens of our fellow-citizens on account of Taxes as well as give relief to the creditors of the United States." 28

In Ontario (1763), flat, fertile land along the Great Lakes and St. Lawrence River also was demarcated in a grid with 6-mile square townships a standard, although there was variation in township and subdivision size across the province. Near lakes, narrow, rectangular long lots also were used (Kain and Baigent 1992, 298-303; Taylor 1945, 90-92; Thomson 1966, 237-43). Similar demarcation was practiced in the south and east of the St. Lawrence in Quebec, called the "Eastern Townships" and the colony of New Brunswick (1784) (Kain and Baigent 1992, 298; Taylor 1945, 89; Thomson 1966, 99, 224-5; Schott 1980). The Dominion Land Survey (DLS), which began in 1871 , was implemented in the Prairie Provinces of Canada to parallel the PLSS in the U.S. with land surveyed into 6-mile square townships that were aligned and addressed along lines of latitude and longitude (Kain and Baigent 1992, 303; McKercher 1986, 21; Taylor 1975, 11; MacGregor, 1981).

\footnotetext{
${ }^{27}$ Linklater (2002, 69-72). As described by Pattison (1957, 49-51), the rectangular survey used Gunter's chain with 10 square chains to the acre; a mile divided into 80 chains; and a square mile in to 640 acres; White (1983).

${ }^{28}$ Ford $(1910,15)$ in describing a letter from Governor Sharp of Maryland to Lard Baltimore in 1754. See also Kain and Baigent (1992, 289-92) and Cazier (1976).
} 
In Victoria, Australia (separated from New South Wales in 1851) RS was used as the agricultural frontier moved northwest beyond Port Philip (Melbourne) in the 1850s. The main cadastral unit for surveying and mapping properties was the parish that varied in size between 15 and 33 square miles. Some parish borders were aligned rectilinearly toward magnetic north, similar to PLSS in the U.S. In the Melbourne-Colac-Geelong triangle to the west of Melbourne, parishes were divided into sections of 640 acres and subdivisions of 80 and 40 acres (Kain and Baigent 1992, 311-13; Powell 1970, 51-68; 1975, 35).

South Australia (1834) was the definitive planned colony. Colonization was organized after 1835 by the South Australian Land Company. Land was surveyed into rectangular grids following Wakefield's philosophy (Winch 1965, 97-110; Burroughs 1967, 179; Oldham 1917, 4, 10, 14; Wakefield 1834, 3-19). Wakefield wanted “...to prevent 'a few good judges of their own interests' from buying up all the available profitable, waste lands" and avoid the "injurious" dispersion of settlement where "each settler became the proprietor of a small section of land; under such conditions society was impossible.... ${ }^{29} \mathrm{~A}$ land registry system designed by Robert Torrens to facilitate the clear assignment of land rights and active land markets was adopted and represented a break from use of English common law deeds of transfer (Kain and Baigent 1992, 313-17; Burroughs 1967, 179; South Australia Department of Lands 1986, 8, 38; Powell, 1972).

The historical data are consistent with the framework in Section III. To more precisely examine the effects of the variables described in the framework, we now turn to econometric analysis of the adoption of a particular regime.

\footnotetext{
${ }^{29}$ Oldham (1917, 14-15), Wakefield (1834, 87-89). Wakefield admired the U.S. federal lands policy (1834, p. 99-103).
} 


\section{B . Econometric Analysis Using Data on Land Characteristics Data and Descriptive Statistics}

With the use of Geographic Information System (GIS) data, we compile a dataset of land characteristics at the colonial level for each area listed in Table 2. Observations are centered at the initial point of British settlement within the colony and include all land area within a 50 mile radius. By overlaying publicly available spatial data we calculate variables for terrain ruggedness, soil quality, area governed and year of settlement. Terrain ruggedness is a measure of average surface slope in a region and is derived from $90 \mathrm{~m}$ digital elevation models (DEMs) generated by the Shuttle Radar Topography Mission (SRTM). Soil quality is the average of a seven-point score where a value of 1 indicates soil unsuitable for agriculture and 7 indicates soil with unconstrained productivity. Source data soil quality comes from the Global Agro-Ecological Zones (GAEZ) dataset. Area governed represents the land area within the boundaries of the observation measured in $1,000 \mathrm{~km}^{2}$. More complete descriptions of how the variables were constructed can be found in the Data Appendix.

Table 3 provides descriptive statistics for the variables in our analysis by

demarcation type. On average, RS is observed over large regions with relatively flat terrain and above average soil quality, which seems to line up nicely with the historical analysis. In addition, the reported means for settlement year suggest an increasing level of order and uniformity in demarcation practices over time.

\section{[Table 3 here]}




\section{Determinants of Adoption: OLS Estimates}

To understand the relative importance of the variables in Table 3, we estimate the decision to adopt a systematic demarcation system by ordinary least squares (OLS) from the following linear regression model ${ }^{30}$

$$
y_{i}=\mu+\alpha T_{i}+\gamma L_{i}+\delta S_{i}+\theta D_{i}+\varepsilon_{i}
$$

where $y_{i}$ is an ordered outcome variable representing the adopted demarcation system in colony $i$ ordered by increasing uniformity. The regressor $T_{i}$ measures terrain ruggedness in colony $i, L_{i}$ is the area governed (size of colony or region), $S_{i}$ is soil quality, $D_{i}$ is the date of initial settlement in years and $\varepsilon_{i}$ is a random error term.

As seen in the historical analysis, accounting for political control and enforcement of demarcation activities appears to play a role in whether a system can be implemented. Areas lacking effective control will have higher costs of implementing systematic demarcation and tend to favor MB by default. This presents a potential problem for econometric interpretation if determinants of political control are correlated with the determinants of adopting a particular system. Therefore we also test the regression model on a restricted sample where pure MB observations are excluded. This ensures the remaining observations are ones where a definitive level of control is observed. OLS estimates for the full and restricted samples are reported in Table 4. Given the linear model, we can loosely interpret the dependent variables as response probabilities and the coefficients as marginal effects. ${ }^{31}$

\section{[Table 4 here]}

\footnotetext{
${ }^{30}$ OLS regression is chosen over a maximum likelihood approach in this analysis because of its preferable small sample properties.

${ }^{31}$ In the case of the full sample, we can interpret the coefficients as two times the marginal effects.
} 
The results show general consistency with our theoretical predictions and historical analysis. Though not significant in the full sample, terrain ruggedness and soil quality have the correct sign predicted from the theory. Terrain ruggedness becomes significant in the restricted sample, perhaps as a result of reduced noise from removing uncontrolled MB observations, and helps to verify the important impact terrain has on surveying costs. The variable for area governed is positive and significant as predicted, and supports the hypothesis that the gains from uniform demarcation increase with the size of the network. The full sample coefficient implies that an increase in 2 million square kilometers, approximately one standard deviation, should increase the likelihood of adopting an RS by $8 \%$. The effect of area governed is slightly larger in the restricted sample and considerably more significant. This possibly suggests that some larger regions in our sample where MB is observed may have adopted an RS system had there been adequate initial control. Lastly, we find a large and significant effect for the year of initial settlement in both samples. Our main interpretation of this effect is that progressive development of survey technology over time lowered the costs and implementation-time of systematic survey. To get a rough idea of the magnitude of this effect, the results suggest that RS adoption in a frontier settlement would be $15 \%$ more likely over a century's time within the time-frame of our sample.

\section{CONCLUSION.}

A half century has passed since Ronald Coase taught economists the importance of the fundamental institutions that underlie markets. He pointed out the link between property rights and transaction costs; how legal and other factors determine them; and how these in turn shape economic outcomes. These insights have influenced subsequent work of economists working on transaction costs, property rights, economic organization, and 
development. ${ }^{32}$ Ironically, the institutions of land - one of Coase's original examples have been neglected in the expansion of institutional economics.

In this paper we have examined the economic history of land demarcation in the expansive British Empire, using the insights of Ronald Coase. We have developed an economic framework for examining the decision to adopt a particular system of demarcation of rights to land. Using that framework we have analyzed the variation in institutions across the temperate British Empire, ranging from the systematic rectangular survey to an organized hybrid, to unsystematic metes and bounds. This variation occurred despite efforts by leading British political economists and colonial politicians, such as Edward Gibbons Wakefield, as well as the British Colonial Office to implement a planned and controlled rectangular survey for the demarcation of land.

We have found that a simple framework that outlines the costs and benefits of implementing the demarcation systems can explain the different institutions that are observed. Once in place, these institutions persist, indicating a strong institutional path dependence that can influence transaction costs, the extent of land markets, and the nature of resource use. The agricultural land institutions that we have examined in the U.S., Canada, Australia, and New Zealand that were put into place between the $17^{\text {th }}$ and $19^{\text {th }}$ centuries, remain in force today. In this regard, institutions of land are durable, much as are other institutions, such as language and law.

\footnotetext{
${ }^{32}$ The list is far too large to do justice to the literatures. Besides those noted earlier, one would certainly include the work of Barzel (1982); Demsetz $(1988,1997)$; Williamson $(1975,1985)$, and others on the theory of the firm.
} 


\section{References}

Acemoglu, Daron, Simon Johnson, and James A. Robinson. 2001. "The Colonial Origins of Comparative Development: An Empirical Investigation," The American Economic Review, 91 (5): 1369-1401.

Acemoglu, Daron, Simon Johnson, James A. Robinson. 2002, "Reversal of Fortune: Geography and Institutions in the Making of the Modern World Income Distribution," The Quarterly Journal of Economics, 117 (4): 1231-1294

Acemoglu, Daron, Simon Johnson, James A. Robinson, 2005, "The Rise of Europe: Atlantic Trade, Institutional Change, and Economic Growth," The American Economic Review, 95 (3): 546-579.

Crosby, Alfred. 1986. Ecological Imperialism: The Biological Expansion of Europe 9001900. New York: Cambridge University Press.

Barnes, Carlton P. 1935. "Economies of the Long Lot Farm", Geographical Review, 25 (April): 298-301.

Barzel, Yoram. 1982. "Measurement Costs and the Organization of Markets," Journal of Law and Economics 25(1): 27-48.

Bogart, Dan and Gary Richardson. 2009. "Making Property Productive: Reorganizing Rights to Real and Equitable Estates in Britain, 1660-1830," European Review of Economic History, 13: 3-30.

Borah, Woodrow W. "The Historical Demography of Aboriginal and Colonial America: An Attempt at Perspective." in The Native Population of the Americas in 1492. William M. Denevan, ed. Madison: University of Wisconsin Press. 1976. 13-34.

Burroughs, Peter. 1967. Britain and Australia, 1831-1855: A Study in Imperial Relations and Crown Lands Administration. Oxford: Clarendon Press.

Coase, Ronald H. 1937. "The Nature of the Firm” Economica, 4 (16) 386-405.

Coase, Ronald H. 1960. "The Problem of Social Cost" Journal of Law and Economics, 3:144.

Coase, Ronald H. 1988. The Firm, the Market and the Law. Chicago: The University of Chicago Press.

Crazier, Lola. 1976. Surveys and Surveyors of the Public Domain, 1785-1975. Washington D.C.: Government Printing Office. 
Darby, H.C. Ed. 1973. A New Historical Geography of England. Cambridge: Cambridge University Press.

Demsetz, Harold. 1988. "The Theory of the firm Revisited," Journal of Law, Economics and Organization 4(1): 141-61.

Demsetz, Harold. 1997. "The Firm in Economic Theory: A Quiet Revolution.” American Economic Review 87(2): 426-29.

Dixit, Avinash. 2003. "Trade Expansion and Contract Enforcement," Journal of Political Economy 111:1293-1317.

Dukeminier, Jesse and James E. Krier, 2002, Property $5^{\text {th }}$ ed. New York: Aspen Law and Business.

Egleston, Melville. 1886. The Land System of the New England Colonies. Baltimore: N. Murray, Publication Agent for Johns Hopkins University.

Ferguson, Niall. 2004. Colossus: The Price of America's Empire. New York: The Penguin Press.

Ford, Amelia Clewly. 1910, reprinted 1976. Colonial Precedents of Our National Land System as it Existed in 1800. Madison: Bulletin of the University of Wisconsin. No. 352. History Series, Vol. 2. No. 2. Reprinted. Philadelphia: Porcupine Press.

Greasley, David and Les Oxley. 2009. "The Pastoral Boom, the Rural Land Market, and Long Swings in New Zealand Economic Growth, 1873-1939." Economic History Review, 62 (2), 324-49.

Johnson, Hildegard Binder. 1957. "Rational and Ecological Aspects of the Quarter Section." Geographical Review 47: 330-48.

Jones, Alan. 1989. Backsight: A History of Surveying in Colonial Tasmania. Hobart: Institution of Surveyors, Australia Inc, Tasmanian Division.

Hailey, Lord. 1938. An African Survey: A Study of Problems Arising in Africa South of the Sahara. London: Oxford University Press.

Harris, R. Cole and Leonard Guelke. 1977 "Land and Society in Early Canada and South Africa." Journal of Historical Geography, 3(2): 135-53

Jeans, D.N. 1966. "The Breakdown of Australia's First Rectangular Grid Survey.” Australian Geographical Studies, IV: 119-28.

Jeans, D.N. 1967. "Territorial Divisions and the Locations of Towns in New South Wales, 1826-1842." Australian Geographer. 19: 243-255. 
Jeans, D. N. 1975. "The Impress of Central Authority upon the landscape: South-Eastern Australia 1788-1850.” Australian Space Australian Time, J.M. Powell and M. Williams, ed. Melbourne, Oxford University Press. 7-12.

Kain, Roger J. P. and Elizabeth Baigent. 1992. The Cadastral Map in the Service of the State: A History of Property Mapping. Chicago: University of Chicago Press.

Kain, Roger J., John Chapman, and Richard R. Oliver. 2004. The Enclosure Maps of England and Wales 1595-1918: A Cartographic Analysis and Electronic Catalogue. New York: Cambridge University Press.

Kinda, Akihiro 2001. "The Concept of 'Townships' in Britain and the British Colonies in the Seventeenth and Eighteenth Centuries." Journal of Historical Geography 27(2): $137-52$.

Labaree, Leonard Woods. Ed. 1967. Royal Instructions to British Colonial Governors, 1670-1776, Vol. II. New York: Octagon Books, Inc.

Lee, D. R., and G. T. Sallee. 1974. "Theoretical Patterns of Farm Shape and Central Place Location," Journal of Regional Science, 14:3 423-30.

Libecap, Gary D. and Dean Lueck, "Land Demarcation and the Role of Coordinating Institutions," NBER Working paper, May 2009.

Libecap, Gary D., Dean Lueck, and Adrian Lopes, “The Effect of Land Demarcation Systems on Agriculture in $19^{\text {th }}$ Century California." Manuscript 2009.

Linklater, Andro. 2002. Measuring America: How the United States was Shaped by the Greatest Land Sale in History. London: Harper Collins

Marschner, Francis J. 1960. Boundaries and Records in the Territory of Early Settlement from Canada to Florida: With Historical Notes on the Cadaster and its Potential Value in the Area. Washington D.C.: Agricultural Research Service, USDA.

MacGregor, James. 1981. Vision of an Ordered Land: The Story of the Dominion Land Survey. Western Producer Prairie Books. Saskatoon, Saskatchewan.

McKay, Anne. ed.1962. Journals of the Land Commissioners for Van Diemen's Land, 1826-28. Hobart: University of Tasmania in conjunction with the Tasmanian Historical Research Association.

McManis, Douglas R. 1975. Colonial New England: a historical geography. New York: Oxford University Press.

Merrill, Thomas and Henry Smith. 2007. Property: Principles and Policies. New York: Foundation Press. 
Mitchell, Robert D. 1983. "American Origins and Regional Institutions: The Seventeenth Century Chesapeake." Annals of the Association of American Geographers 73 (2): 404-20.

North, Douglass C. 1990. Institutions, Institutional Change and Economic Performance. New York: Cambridge University Press.

North, Douglass C, John Joseph Wallis, and Barry R. Weingast. 2009. Violence and Social Orders: A Conceptual Framework for Interpreting Recorded Human History. New York: Cambridge University Press.

Oldham, Wilfrid. 1917. The Land Policy of South Australia from 1830 to 1842. Adelaide: G. Hassell \& Son.

Price, Edward T. Price. 1995. Dividing the Land: Early American Beginnings of Our Private Property Mosaic. Chicago: University of Chicago Press.

Pattison, William D. 1957. Beginnings of the American Rectangular Land Survey System, 1784-1800, Department of Geography Research Paper No. 50, University of Chicago.

Pool, D. Ian. 1977. The Maori Population of New Zealand 1769-1971. Auckland: University of Auckland Bindery.

Posner, Richard A. 2002. Economic Analysis of the Law, $6^{\text {th }}$ ed. Boston: Little, Brown.

Powell, J.M. 1970. “The Victorian Survey System, 1837-1860.” New Zealand Geographer. 26(1): 50-69.

Powell, J.M.1972. "The Records of the New Zealand Lands and Survey Department." New Zealand Geographer, 28: 72-77.

Powell, J.M. 1975. “Conservation and Resource Management in Australia 1788-1860.” In Australian Space Australian Time, Edited By J.M. Powell and M. Williams. Melbourne, Oxford University Press, 18-60 1975

Reps, John W. 1965. The Making of Urban America. Princeton: Princeton University Press.

Richardson, Gary and Dan Bogart. 2008. "Institutional Adaptability and Economic Development: The Property Rights Revolution in Britain, 1700 to 1830." Cambridge, MA: NBER working paper 13757.

Richeson, A.W. 1966. English Land Measuring to 1800: Instruments and Practices. Cambridge: MIT Press. 
Schott, Carl. 1936. Landnahme und Kolonisation in Canada, am beispiel Siidontarios (Kiel 1936), 83-101, translated, 1980, by Andrew Burghardt; maps redrawn by Margaret Chan. McMaster University, Canadian Geographer, 25 (1), 1981, 77-93.

Scott, James C. 1998. Seeing Like a State: How Certain Schemes to Improve the Human Condition have Failed. New Haven: Yale University Press.

Shavell, Steven 2004. Foundations of Economic Analysis of Law. Cambridge: Harvard University Press.

South Australia, Department of Lands 1986. The Measure of the Land, Adelaide.

Taylor, Griffith. 1945. "Towns and Townships in Southern Ontario." Economic Geography. 21 (2): 88-96.

Taylor, W. A. 1975. "Crown Lands: A History of Survey Systems." Registries and Titles Department. Victoria, B.C.: Ministry of Sustainable Resource Management.

Thomson, Don W. 1966. Men and Meridians: The History of Surveying and Mapping in Canada. Volume I: Prior to 1867. Ottawa: Queen's Printer.

Thrower, Norman J. W. 1966. Original Survey and Land Subdivision: A Comparative Study of the Form and Effect of Contrasting Cadastral Surveys. Association of American Geographers. Chicago: Rand McNally and Co.

Torrens, Robert. 1821. An Essay on the Production of Wealth. London: Longman, Hurst, Rees, Orme, and Brown.

Turner, Michael E. 1980. English Parliamentary Enclosure: Its Historical Geography and Economic History. Hamden, Connecticut: Dawson.

Vamplew, Wray. ed. 1987. Australian Historical Statistics. Sydney: Fairfax, Syme, and Weldon.

Wakefield, Edward Gibbon. 1834. The British Province of South Australia or a Description of the County, Illustrated by Charts and Views with an Account of the Principles, Objects, Plan and Prospects of the Colony. London: William Clowes.

Wakefield, E.G., Wakefield, E. J., Godley, J. R. 1868. The Founders of Canterbury: Being Letters from the late Edward Gibbon Wakefield to the late John Robert Godley, and to Other Well-Known Helpers in the Foundation of the Settlement of Canterbury in New Zealand. Christchurch, New Zealand: Stevens \& Co.

White, C. Albert. 1983. A History of the Rectangular Survey System. Washington D.C.: Government Printing Office. 
Winch, Donald. 1965. Classical Political Economy and Colonies. Cambridge: Harvard University Press.

Williams, M. 1975. "More and Smaller is Better: Australian Rural Settlement 1788-1914." In Australian Space Australian Time, Edited By J.M. Powell and M. Williams. Melbourne, Oxford University Press. 1975, 61-103.

Williamson, Oliver E. 1975. Markets and Hierarchies, Analysis and Antitrust Implications: A Study in the Economics of Internal Organization. New York: Free Press.

Williamson, Oliver E. 1985. The Economic Institutions of Capitalism: Firms, Markets and Relational Contracts. New York: Free Press.

Yelling, James. 1977. Common Field and Enclosure in England, 1450-1850. Hamden, Connecticut: Archon Books.

Young, Arthur. 1808. General Report on Enclosures. Drawn Up by Order of the Board of Agriculture, London: B. McMillan 


\section{Appendix: Variables and Data Sources}

Observations: Observations are centered at the initial point of British settlement and include all land area within a 50 mile radius. For the US Public Land Survey we use the 'Point of Beginning' located in present day East Liverpool, Ohio at the coordinates $40^{\circ} 38^{\prime} 32.61^{\prime \prime} \mathrm{N} 80^{\circ} 31^{\prime} 9.76^{\prime \prime} \mathrm{W}$. For the Dominion Land Survey of Canada we use the center of Winnipeg as the initial point. Coordinates for initial settlements were obtained from http://facstaff.unca.edu/mcmcclur/GoogleMaps/Projections/GoogleCoords.html.

Terrain Ruggedness: Measures average surface slope for the region (see Libecap Lueck 2009). The measure is derived from $90 \mathrm{~m}$ digital elevation models (DEMs) downloaded from http://srtm.csi.cgiar.org. The DEMs are generated from NASA's Shuttle Radar Topography Mission (SRTM) and further processed by the International Centre for Tropical Agriculture (CIAT) to fill voids in the dataset. We exclude water bodies in our measure of terrain ruggedness. This was done by removing areas in the DEM which overlap data from the SRTM Water Body Database (SWBD). SWBD data was obtained online from http://dds.cr.usgs.gov/srtm/version2_1/SWBD.

Soil Quality: Based on a seven-point score measuring constraints on soil fertility from the Global Agro-Ecological Zones (GAEZ) dataset downloaded at 30 arc second resolution from http://www.iiasa.ac.at/Research/LUC/GAEZ. We reverse the order of the GAEZ ranking to reflect quality of the soil rather than constraints. A score of 1 indicates soil unsuitable for agriculture. Scores 2-6 indicate soil suitable for agriculture but with constrained productivity and severity of constraints decreasing with score. A score of 7 indicates unconstrained soil. The final measure is an average over the area of the observation.

Year of Settlement: Initial year of settlement was obtained from http://www.britishempire.co.uk/timeline/colonies.htm. The earliest year listed for each colony is used for the analysis with the exception of New Zealand and Victoria, 1840 and 1851 respectively, in which we use the year they separated from New South Whales. Initial years for the PLSS and DLS are 1785 and 1871 respectively.

Area Governed: Measured as the land area of the territory in $1,000 \mathrm{~km}^{2}$. Current boundaries of Ontario and Quebec were used to determine area for Upper and Lower Canada respectively. Area under the Dominion Land Survey was calculated as the collective area of the provinces Manitoba, Saskatchewan, and Alberta. Area under the U.S. Public Land Survey System was calculated as the collective area of all U.S. states not included in our sample with the exceptions of Hawaii, Texas, Louisiana, New Mexico, California, Alaska, Kentucky, West Virginia, Tennessee and Vermont. Area for New Zealand territories were adapted from the map in Kain and Baignet (1984, 319, Figure 8.30). Area for all other observations use current boundaries. 
Table 1: Three Land Demarcation Regimes

\begin{tabular}{llll}
\hline Characteristic & $\begin{array}{l}\text { Rectangular } \\
\text { Survey }\end{array}$ & Mixed & Metes and Bounds \\
\hline Controlled entry & Yes & Yes & No \\
Prior survey & Yes & Yes & No \\
Plot shape & Rectilinear & Varies & Idiosyncratic \\
Plot alignment & Yes (often N-S) & Varies & No \\
Fully contiguous & Yes (within region) & Varies & No \\
\hline
\end{tabular}


Table 2: Land Demarcation Systems in the British Empire

\begin{tabular}{ll}
\hline Jurisdiction & Demarcation System \\
\hline U.S. Federal Lands & RS \\
Canadian Dominion Lands & RS \\
South Australia & RS \\
Ontario, Canada & RS \\
Victoria, Australia & RS \\
New Zealand: Otago & MX \\
New Zealand: Nelson & MX \\
New Zealand: Wellington & MX \\
New Zealand: Canterbury & MX \\
New Zealand: Hawkes Bay & MX \\
New Zealand: Taranaki & MX \\
Connecticut & MX \\
Rhode Island & MX \\
Massachusetts & MX \\
Maine & MX \\
New Hampshire & MX \\
Nova Scotia & MX \\
New Brunswick & MX \\
Quebec & MX \\
Georgia & MB \\
South Carolina & MB \\
North Carolina & MB \\
Virginia* & MB \\
Maryland & MB \\
Delaware & MB \\
Pennsylvania & MB \\
New Jersey & MB \\
New York & MB \\
New South Wales & MB \\
Tasmania & MB \\
Queensland & West Australia \\
Sources: See text. * includes what is now Kentucky and West Virginia.
\end{tabular}


Table 3: Summary Statistics by Demarcation Type

\begin{tabular}{lcccc}
\hline $\begin{array}{l}\text { System } \\
\text { Type }\end{array}$ & $\begin{array}{c}\text { Terrain } \\
\text { Ruggedness }\end{array}$ & $\begin{array}{c}\text { Soil } \\
\text { Quality }\end{array}$ & $\begin{array}{c}\text { Area Governed } \\
\left(10,000 \mathrm{~km}^{2}\right)\end{array}$ & $\begin{array}{c}\text { Year of } \\
\text { Settlement }\end{array}$ \\
\hline MB (13) & 1.61 & 3.01 & 45.7 & 1707 \\
& $(1.39)$ & $(0.74)$ & $(78.7)$ & $(75)$ \\
MX (14) & 2.36 & 3.34 & 13.7 & 1746 \\
& $(1.33)$ & $(.97)$ & $(35.4)$ & $(99)$ \\
RS (5) & 1.09 & 4.32 & 283.2 & 1827 \\
& $(0.65)$ & $(1.63)$ & $(373.9)$ & $(37)$ \\
Total (32) & 1.85 & 3.39 & 68.8 & 1743 \\
\hline
\end{tabular}

Notes: Means for each system type are reported with standard deviations below in parentheses.

Table 4: OLS Regression Results

\begin{tabular}{|c|c|c|c|c|c|c|}
\hline Dependent Variable & $\begin{array}{c}\text { Terrain } \\
\text { Ruggedness }\end{array}$ & $\begin{array}{c}\text { Soil } \\
\text { Quality }\end{array}$ & $\begin{array}{c}\text { Area } \\
\text { Governed }\end{array}$ & $\begin{array}{c}\text { Year of } \\
\text { Settlement }\end{array}$ & $\mathrm{R}^{2}$ & F Stat \\
\hline $\begin{array}{l}\mathrm{MB}=0, \mathrm{MX}=1, \mathrm{RS}=2 \\
(32 \mathrm{Obs})\end{array}$ & $\begin{array}{c}-0.117 \\
{[0.086]}\end{array}$ & $\begin{array}{c}0.141 \\
{[0.137]}\end{array}$ & $\begin{array}{l}.00078^{*} \\
{[.00044]}\end{array}$ & $\begin{array}{l}0.0038^{*} \\
{[0.0011]}\end{array}$ & 0.32 & 5.5 \\
\hline $\begin{array}{l}M X=0, R S=1 \\
(19 \text { Obs })\end{array}$ & $\begin{array}{c}-0.171 * * \\
{[0.069]}\end{array}$ & $\begin{array}{c}0.031 \\
{[0.080]}\end{array}$ & $\begin{array}{l}.00086^{* *} \\
{[.00020]}\end{array}$ & $\begin{array}{l}0.0028 * * \\
{[0.0007]}\end{array}$ & 0.65 & 33.6 \\
\hline
\end{tabular}

Notes: OLS coefficient estimates are reported. Heteroskedasticity-consistent standard errors are in brackets.

$* * \mathrm{p}<0.05, * \mathrm{p}<0.1$ 


\section{Figure 1: The British Empire and Temperate Colonies ${ }^{33}$}

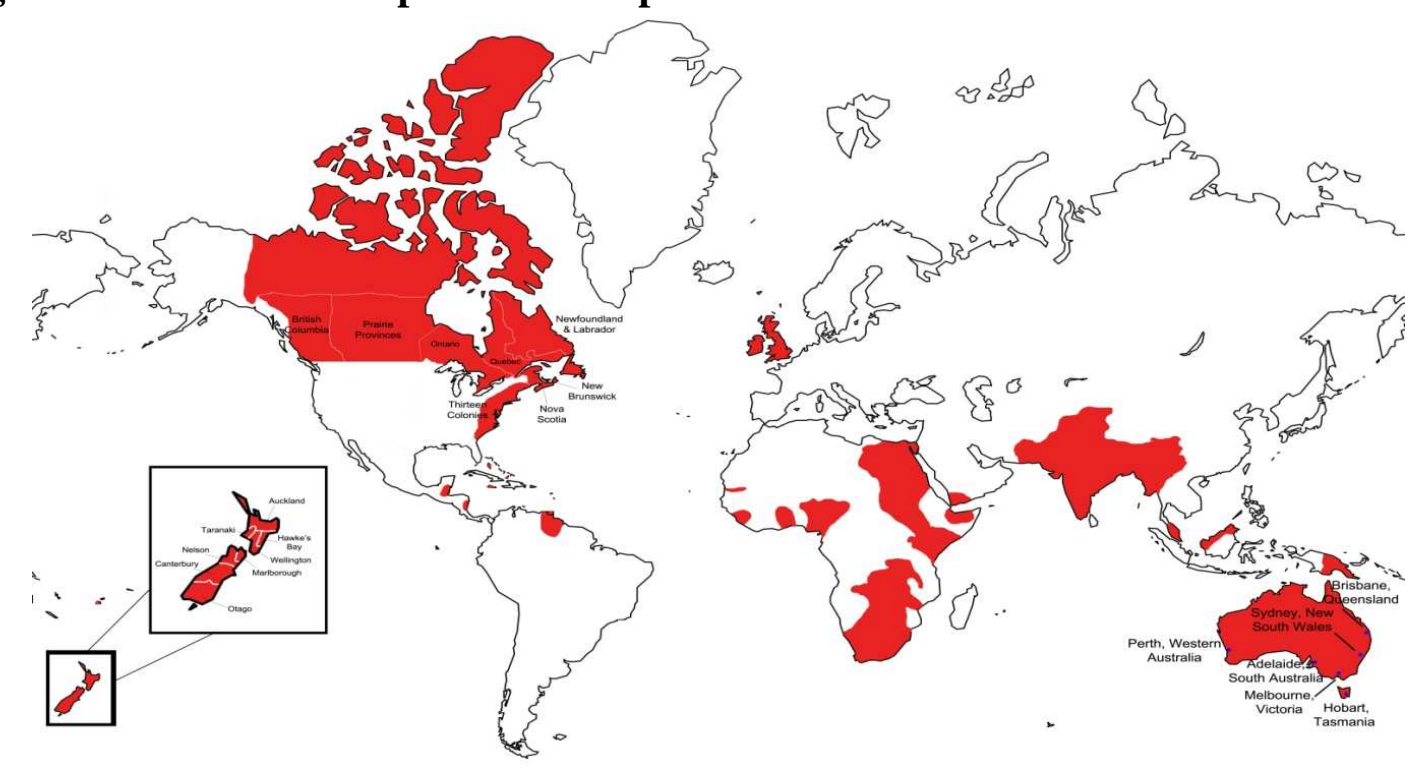

\section{Figure 2: Early U.S. Demarcation Systems}

Federal rectangular grid

Irregular land division

Land settled and subdivided

by townships

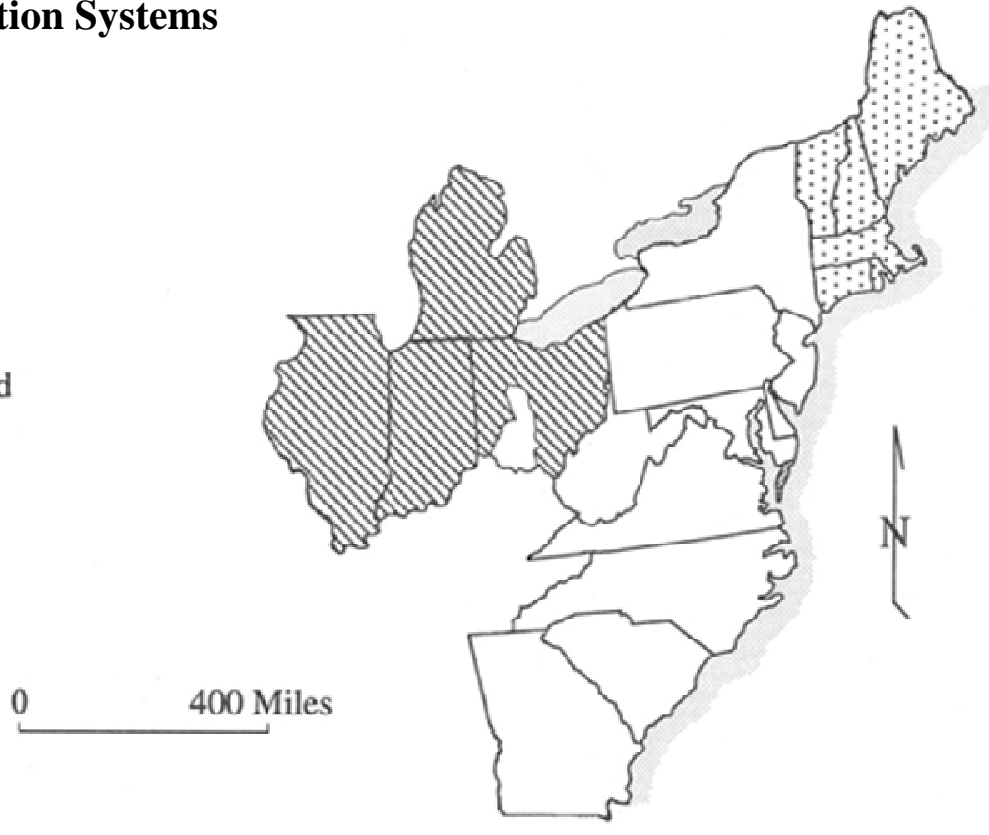

Source: Adapted from Price $(1995,8)$. Price's Federal rectangular grid corresponds to our RS; Townships to our Mixed Demarcation; and Irregular to our MB classification.

\footnotetext{
${ }^{33}$ The figure is modified from the figure provided in http://meta.wikimedia.org/wiki/File:British Empire evolution.gif
} 


\section{Figure 3: Land demarcation practices in the British colonies}

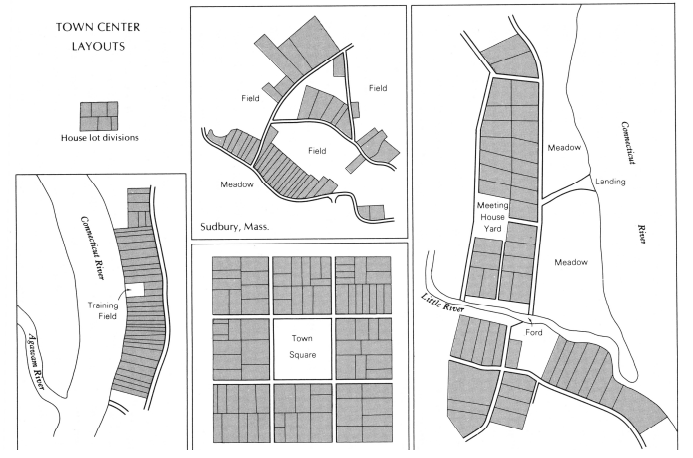

Mixed Demarcation, New England Townships

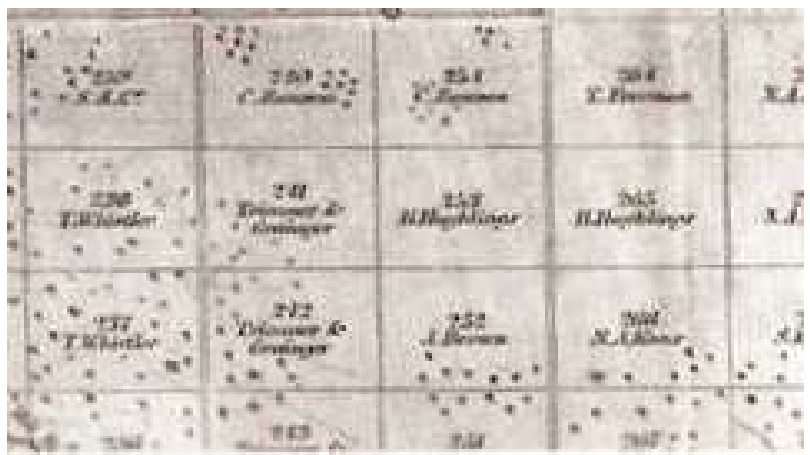

RS Demarcation, South Australia

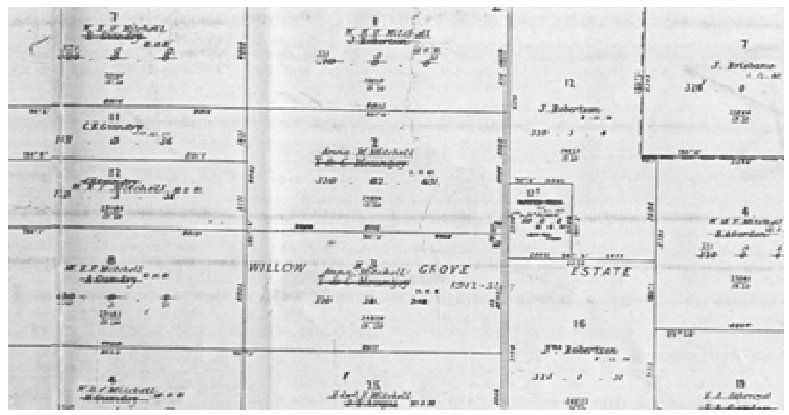

RS Demarcation Victoria, Australia

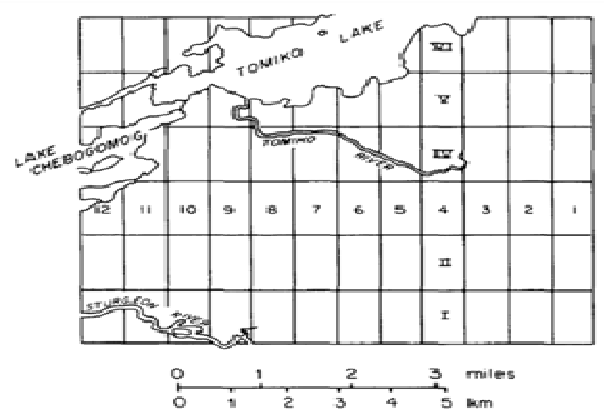

RS Demarcation, Ontario, Canada

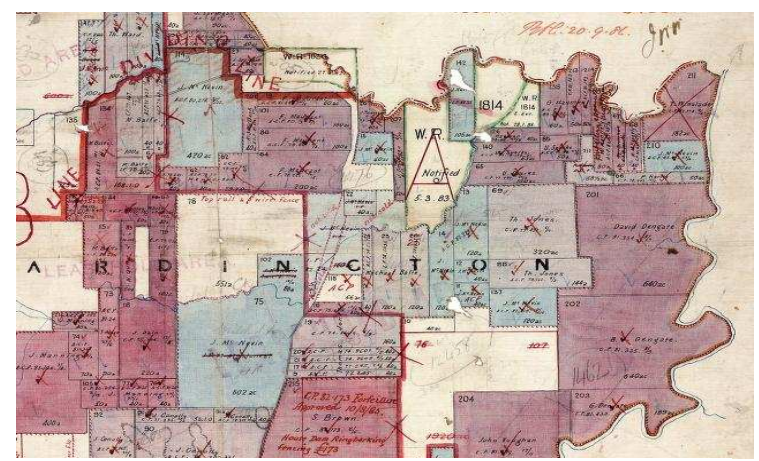

MB Demarcation, New South Wales,

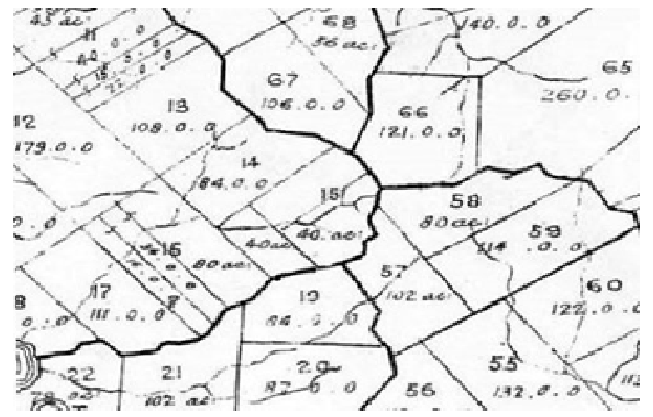

Mixed Demarcation, New Zealand

Sources: New England: McManis (1975, 56); Ontario: Schott (1936, reprinted, 1981, 84); South Australia: Kain (1992, 315); New South Wales: http://parishmaps.lands.nsw.gov.au/mrsid/show_map.pl?client=pmap\&image=PMapEast02/10075001.sid\&m apval1=CARDINGTON\&mapval2=560\&maptype=PL; Victoria: http://www.honeycombearchive.com/thegreatwork/10maps/html/map04.html; New Zealand: http://sites.google.com/a/aotea.org/donarmitage//rsrc/1233729039315/Home/great-barrier-island-history/maps---charts-of-great-barrierisland $/ 1880 \% 20 \mathrm{map} \% 20 \mathrm{gbi} 2 . j p g$ 